\title{
SCHIZOPHRENIA
}

Schizophrenia is a field of continuing importance to psychiatry and its relationships with other medical specialities, and many new findings with regard to its classification, diagnosis and pathology have emerged in recent years.

This symposium will provide a broad update of these issues, but will also tackle some of the treatment and management problems, creating a forum to meet and discuss both the practical and educational needs of clinicians and others in related fields.

Guest speakers will include Dr T. J. Crow, Dr R. M. Murray, Dr J. P. Leff, Dr M. A. Reveley, Dr D. A. W. Johnson and Professor S. R. Hirsch.

The symposium will be held at the Royal Society, 6 Carlton House Terrace, London SW1 on Friday 14 March 1986, commencing at 9.30 am and finishing at approximately $5.00 \mathrm{pm}$.

The cost of registration will be $\mathbf{f 3 0}$. For further details of speakers and their specific topics, and registration form, please contact Christine McSorley, at Charter Clinic Chelsea, 1/5 Radnor Walk, London SW3 4PB. Tel: 01-351 1272.

\section{Charter Clinics}

\section{Index to Advertisers}

Pharmacenticals

The Boots Company plc ........... facing $\mathrm{p} 46$

E. R. Squibb \& Sons Limited ......... facing p 46

Clinics, Hospitals and Nursing Homes

Bowden House Clinic.$\ldots \ldots \ldots \ldots \ldots \ldots$ p iv

Charter Clinic ............... inside back cover

\section{Surgical and Medical Appliances}

Ectron Limited
Booksellers and Publishers

Oxford University Press .............. p iii

The Royal College of Psychiatrists -

Gaskell ................. facing $\mathrm{p} 47$

\section{Appointments}

Alberta Hospital Edmonton ............ p ii

British Columbia Ministry of Health .... facing $\mathrm{p} 47$

Edmonton General Hospital ........ facing $\mathrm{p} 87$

The Home Office ................... p iii

University of Maryland $\ldots \ldots \ldots \ldots \ldots \ldots$ p iii 


\section{THE BRITISH JOURNAL OF PSYCHIATRY}

\section{January 1986 \\ Volume 148}

\section{Papers}

The Measurement of Social Behaviour in Psychiatric Patients: An Assessment of the Reliability and Validity of the SBS Schedule; Til Wykes and E. Sturt

Life Events and Schizophrenia: A Saudi Arabian Study; M. A. F. Al-Khani, P. E. Bebbington, J. P. Watson and F. House

A Validity Study of a Psychiatric Screening Questionnaire (SRQ-20) in Primary Care in the City of São Paulo; Jair de Jesus Mari and Paul Williams

A Baseline Study on Mental Disorders in Guiné-Bissau; Joop T. V. M. de Jong, Guus A. J. de Klein and Sineke G. H. M. M. ten Horn

Outcome of Patients Committed to Hospital under the Mental Health (Scotland) Act 1960; A. A. McKechnie, A. Corser and V. R. Mc Millan

Adverse Drug Reactions to First- and Second-Generation Antidepressants; A Critical Evaluation of Drug Surveillance Data; $L$. G. Schmidt, R. Grohmann, B. MüllerOerlinghausen, H. Ochsenfahrt and P.S. Schönhöfer

Mydriatic Response to Topical Naloxone in Opiate Abusers; A. H. Ghodse, T. H. Bewley, M. K. Kearney and S. E. Smith

Imipramine and Amitriptyline Plasma Concentrations and Clinical Response in Major Depression; James H. Kocsis, Israel Hanin, Charles Bowden and David Brunswick

Raised Plasma Cortisol Concentrations are a Feature of Drug-Free Psychotics and are not Specific for Depression; J. E. Christie, L. J. Whalley, H. Dick, D. H. R. Blackwood, I. M. Blackburn and G. Fink

Dexamethasone Concentrations and the Dexamethasone Suppression Test in Psychiatric Disorders; Howard Morris, Vaughan Carr, Judy Gilliland and Michael Hooper

Depression, Urinary Free Cortisol Excretion and Lymphocyte Function; Ziad Kronfol, J. Daniel House, Joseph Silva Jr., John Greden and Bernard J. Carroll

Hormones, Mood and Sexuality in Lactating Women; E. M. Alder, A. Cook, D. Davidson, C. West and J. Bancroft

Computed Tomography in the Elderly: Changes over Time in a Normal Population; Jonathan M. Bird, Raymond Levy and Robin J. Jacoby

Pseudodementia: Facts and Figures; A. Bulbena and G. E. Berrios

\section{Comment}

Should Plasma or Urinary MHPG be Measured in Psychiatric Research? A Critical Comment; Johannes G. Filser, Walter E. Müller and Helmut Beckmann

Brief Reports

Short-Term Intensive Psychotherapy - A Case History; Richard Gillett

True Auditory Hallucinations as a Conversion Symptom; Chittaranjan Andrade and Shoba Srinath

Hypomania following Cognitive Therapy; David Kingdon, Patt Farr, Siobhan Murphy and Peter Tyrer

A Hundred Years Ago; researched by Henry Rollin

Notice to contributors, subscribers and advertisers inside front cover 